\title{
Developing Social Skills and Social Competence in Children with Autism
}

\author{
Tracey Silveira-Zaldivara, Gül Özerk ${ }^{b}$, Kamil Özerk,o
}

\author{
Received \\ Revised \\ Accepted \\ $\mathrm{DOI}$ \\ - Tracey Silveira-Zaldivar, \\ Orange Unified School District, California, USA. \\ E-mail: drimmune@yahoo.com \\ ORCID: https://orcid.org/0000-0002-9521-7207 \\ ${ }^{b}$ Gül Özerk, \\ Oslo Metropolitan University, Oslo, Norway. \\ E-mail: Gul.Ozerk@oslomet.no \\ ORCID: https://orcid.org/0000-0001-6205-0300 \\ COrrespondance Details: Kamil Özerk \\ University of Oslo, Norway. \\ E-mail: Kamil.Ozerk@iped.uio.no \\ ORCID: https://orcid.org/0000-0003-1770-0153
}

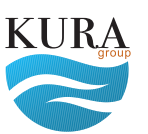

Copyright (C)

www.iejee.com

ISSN: 1307-9298
(C) 2021 Published by KURA Education \& Publishing. This is an open access article under the CC BYNC- ND license. (https://creativecommons.org/ licenses/by/4.0/)

\begin{abstract}
Social development is one of the most critical developmental areas for human beings. Deficits in social skills may negatively impact several essential domains including academic achievement, interpersonal relationships, behavior, mental health, and adult life outcome. Individuals with autism present with core deficits in social skills. Without supports and effective interventions to enhance social skills, children with autism often struggle to obtain social competence, and may experience challenges in the school, home, and community settings. With effective interventions, children with autism can learn essential social skills that can help to mitigate deficits and strengthen social competence. After a brief review of various theories of social development, this article seeks to present the constructs of social competence, social skills, and adaptive skills in relatable and clear language for educators. Finally, the article will review several evidence-based interventions designed to enhance social skills.
\end{abstract}

\section{Keywords:}

Social Competence, Social Development, Social Skills,

Evidence-Based Practices, Children, Autism

\section{Introduction}

Interest in the role of social interaction for human development has occupied theoreticians in the last century. John Dewey (1938) considered all learning as an activity that is social in nature. Dewey theorized that effective education is derived from social interaction, cooperation, and collaboration. Dewey, therefore, progressively argued for the creation of educational environments that included developmentally appropriate and engaging social learning experiences for children. Dewey's contemporary social psychologist George Herbert Mead (1934) contended that one cannot learn to be social in a vacuum and that social interaction was a prerequisite for learning. Similarly, Jerome Bruner proposed, "The infant's principal "tool" for achieving his ends is another familiar human being." (Bruner 1983, p. 26). Bruner interpreted social interaction as both selfpropelling and self-rewarding. The Russian educational psychologist Lev S. Vygotsky (1978) distinguished between 'inter-psychological processes' and 'intra-psychological processes.' The former has to do with social interaction, cooperation, and collaboration which takes place between 


\section{iejee $\approx$}

people, and the latter with cognitive processes within a person. Vygotsky (1978) touted that every function in the child's cultural development appears twice: first, on the social level, and later, on the individual level (p. 57). Vygotsky considered play (particularly roleplay and collaboration with competent peers and/or adults) as critical for social development. In a social role-play scenario, a child simulates an older person in a particular profession or engaging in a particular task (such as a pretending to be a doctor or pretending to drive a car). In Vygotsky's social role play, an adult would use their language and social skills to stimulate the development of a child. Vygotsky theorized that a child could improve their level of social development via assistance from a more competent partner and through rehearsal of inter-psychological processes. Like other social educators of his time, Vygotsky professed that every child's individual learning has a social basis, "Human learning presupposes a specific social nature and a process by which children grow into the intellectual life of those around them" (p. 88). Similar to Dewey and Vygotsky, Piaget postulated that one's social interaction in the early years has implications for future social development (1977). Two core principles underlie the theories of progressive social educators:

1. Providing children with appropriate conditions for social learning is critical for their overall development.

2. Significant others play a crucial role in the process of social development.

These core principles will guide our discussion of the importance of social skills and the need to implement evidence-based social skills interventions for children who present with social deficits.

The psychological and educational ideas that underline the importance of social interaction and social development by influential scholars is just as relevant today as they were at the time they were formulated. During the past two decades, the topics of social skills, social development, and social competence have received increased attention. Not surprisingly, the increased focus on the importance of social development has corresponded with the rising rate of autism. Currently, nearly 1 in 54 children has been identified with autism spectrum disorder (ASD) according to estimates from the Center for Disease Control's (CDC) Autism and Developmental Disabilities Monitoring (ADDM) Network (ADDM, 2020) compared to 1 in 150 in the year 2000. As the prevalence of autism has surged, public school systems have seen a similar upwelling in the population of school children with autism. Per the Diagnostic and Statistical Manual of Mental Disorders, 5th edition (DSM-5), a hallmark criterion of autism is persistent deficits in social communication and social interaction across multiple contexts (APA, 2013). The International Classification of Diseases 11th edition (ICD-II), a guide developed by the World Health Organization in 2018, has described autism as follows:

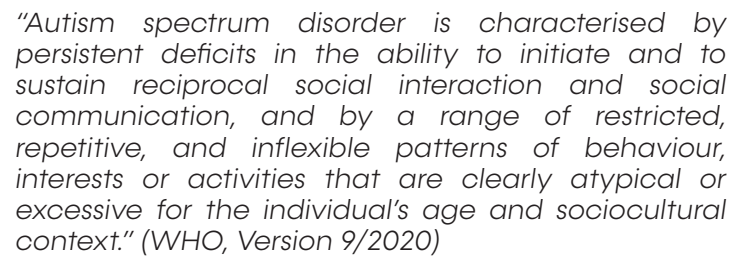

As Kasari and Patterson (2012) postulated, "Social impairment may be the most complex and impenetrable core challenge facing children with autism" (p. 713). As challenges in social communication, social interaction, and the ability to initiate and sustain reciprocal social interaction are primary characteristics of children with autism spectrum disorder (ASD), the need to target the area of social development for children with autism is paramount to their success.

\section{The Purpose Of The Article}

The purpose of this article is threefold. This article seeks to elaborate upon the impact of social skills deficits for individuals with autism, underlining the importance of social skill development for students with autism. Secondly, the article seeks to present the constructs of social competence, social skills, and adaptive skills, in practical and relatable terms for practitioners and educators. Finally, the article will review evidencebased practices that are suitable for the development of social skills for children and adolescents with ASD and other conditions.

\section{The Impact of Social Skills}

As described in the DSM5 and ICD-II, social interaction and communication deficits are key characteristics of autism. There are several connections between these two types of impairments (APA, 2013; Hansen et al., 2014; Tager-Flusberg, 2003). Students with autism often have difficulties with pragmatics, commonly referred to as social language (Carter, et al., 2005; Miller et al., 2015; Staikova et al., 2013). Difficulties in pragmatics can be manifested by any of the following behaviors: eye contact, reciprocal conversation, turn taking, topic maintenance, greetings, speech prosody, understanding figurative language, and/ or understanding emotions and non-verbal body cues (Shaked \& Yirmiya, 2003; Tager-Flusberg, 2003; Tierney et al., 2014). Social communication deficits contribute to the likelihood of social isolation and reduce prospects for social engagement (Miller et al., 2015; Wetherby et al., 2007). Challenges in the functional use of communication have been linked to behavioral difficulties. When students are stymied when attempting to express wants and/or needs and/or emotions (Carter et al., 2005; Jones et al., 
2017) maladaptive behavior may result. Difficulties in joint attention (the involvement of shared attention or shared experiences) may impede the development of appropriate and reciprocal play (Hwang \& Hughes, 2000; Ingersoll \& Schreibman, 2006; Kasari et al., 2015; Pierce-Jordan \& Lifter, 2005; Silveira-Zaldivar, 2019). Kasari and Patterson (2012) concluded that the challenges that children with autism encounter when engaging jointly with others adversely impacts the quantity and quality of interaction with others. Furthermore, many children with ASD exhibit a lack of awareness of others that further contributes to difficulties in social interaction. According to several studies (Calder et al., 2013; Carter et al., 2014; Kasari et al., 2012; Reichow et al., 2012) social demands tend to increase for children with ASD for each passing year and grade, resulting in amplified social challenges.

For young individuals with autism, deficits in social skills and communication underscore a myriad of challenges and lost opportunities across a lifetime (Cidav et al., 2012; Ingersoll et al., 2001). Social difficulties may negatively impact academic achievement and school attendance, mental health, and behavior (Lauderdale-Litten et al., 2013; Mazurek et al., 2013; Munkhaugen et al., 2017; Patton et al., 2016; Rabiner et al., 2016). Furthermore, deficits in social skills can dramatically impact future life success across various domains including relationships, employment, health, and higher education (Denham \& Brown, 2010; Montroy et al., 2014; Zins, et al., 2004; Silveira-Zaldivar, 2019).

Deficits in social skills have been demonstrated to negatively impact interpersonal relationships. Children with ASD have fewer friends and report a lower quality of friendships than typical peers (Calder et al., 2013; Cook et al., 2017; Kasari et al., 2011). Children with ASD tend to experience greater isolation and loneliness than peers (Goldsteinet et al., 1992; Kasari et al., 2011; Locke et al., 2010). On average, students with autism spend $30 \%$ of recess time alone, while typical peers spend $9 \%$ of recess alone (Locke et al., 2016). While research shows that many children with ASD experience social isolation, this is not always due to lack of motivation for contact with others (Rumsey et al. 1985; Orsmond et al. 2004; Kasari \& Patterson, 2012), but, rather, due to poor social skills (Koegel \& Koegel, 2006; Kasari \& Patterson, 2012; Schreibman et al., 2015). Students with autism also experience greater rejection and bullying from others (Hebron et al., 2015; Schroeder et al., 2014). Furthermore, individuals with autism are less satisfied with their own social functioning and interpersonal relationships than typical peers (Friend \& Bursack, 2009; Magiati et al., 2013). Children with autism report higher levels of co-morbid mental health concerns. Compared to children diagnosed with just anxiety alone, those with comorbid autism and anxiety experience more specific phobias, higher levels of total anxiety and social anxiety, more frequent panic attacks, and an overall lower quality of life (Van Steensel et al., 2012). In addition to anxiety, many individuals with autism from young children to adults, struggle with depression (Berney, 2004; Gotham, Brunwasser, \& Lord, 2015; Hillier et al., 2011). Anxiety and depression may be considered a biproduct of the difficulties that young individuals with autism experience with emotional regulation (Santomauro et al., 2016).

The social skill deficits of a child with autism may not only negatively impact the child, but parent caregivers, educators, community members, peers, and service providers, as well. Zablotsky, Bramlett, and Blumberg (2015) found that parent ratings of the severity of their child's autism correlated directly with the impact of the child's condition on the family in terms of the parents' financial stress and the parents' ability to maintain employment. Caring for a child with ASD can significantly increase parental anxiety and depression, while simultaneously decreasing financial resources and one's overall quality of life (Meadan et al., 2010; Nik Adib et al., 2019; Taylor \& Henninger, 2015). Nealy et al. (2012) interviewed several mothers of children with autism and found the mothers experienced commonalities: (a) autism leaves an emotional impact (such as undertones of stress, guilt, and anxiety); (b) autism may leave a social impact (such as reduced time for friends, tense spousal relations, and strained child-parent bonds with other siblings); and (c) autism often leaves a negative financial impact. Like many of their parents, siblings of children with autism report heightened levels of stress and worry (Petalas et al., 2012). Furthermore, teachers and other caregivers, such as day care providers, have reported increased anxiety levels and stress working with children with autism (Corona et al., 2017; Witherell, 2013). Inclusion has been linked to higher rates of teacher burnout, particularly for inclusion regular education teachers who have not had the benefit of the training that their special education teacher counterparts have experienced (Boujut et al., 2016; Lindsay et al., 2013).

The long-term effect of deficits in social competence can be profound. Teachers and parents have rated social skills, goal directedness, and emotional stability as more likely to lead to school and life success than variables such as IQ and aptitude (Getzels \& Jackson, 1961, Jones et al., 2015). Jones, Greenberg, and Cowley (2015) reviewed teacher assessments of the social competence of nearly 1,000 kindergarten students and followed them from between 13 to 19 years later to assess the impact of social competency on multiple measures. The results showed statistically significant associations between kindergarten social skills and young adult outcomes in (a) employment, (b) higher education, (c) criminality, (d) chemical dependency, and $(e)$ mental health. Adults with autism experience greater levels of anxiety and depression (Hillier et 


\section{iejee $\approx$}

al., 2011; Van Steensel et al., 2012), and they are more dependent upon government assistance than typical peers (Mordre et al., 2012). An overwhelming 50\% of young adults with autism (ages 19-23) have not held a job or attended postgraduate education after leaving high school (Shattuck et al., 2012). Given two individuals with autism of at least average to above average cognition, studies have found that the individual who is most likely to succeed in life is the individual who is more socially competent (Mordre et al., 2012; Szatmari et al., 2003). Students with milder social deficits tend to have smoother transitions to middle school (Makin et al., 2017) than those with more severe deficits and students with milder social deficits are more likely to be mainstreamed than their peers (Brown \& Mclntosh, 2012; Fulton et al., 2014).

According to Baron-Cohen (1995; 2001) the primary social challenges that affect children with ASD is related to their lack of perspective taking. BaronCohen (2001) elaborates that challenges in perspective taking can lead to a lack of empathy or a state of mind-blindness.

From the social constructionist perspective (Mead, 1934; Vygotsky, 1986), we ascertained that social roleplaying (the changing of one's behavior to assume a role) is an important social skill which contributes to the development of the ability of perspective taking and language skills. It is possible to conclude, therefore, that difficulties in perspective taking may naturally impede an individual's ability to engage in social role play, which is considered by many to be a critical component in the development of social skills. Research has also shown that irregularities in the brain's Amygdala and Cerebral cortex may contribute to social-skills-related problems for children with ASD (Jansen \& Holck, 2020, Rutter \& Pine, 2015; Tsilioni, 2020). Whatever the origin of the social challenges, the social deficits experienced and manifested by individuals with ASD are undeniable and can profoundly impact the success of the individual with autism. Fortunately, studies have shown that by investing in evidencebased practices that enhance social development, individuals can effectively teach social skills to children and adolescents with ASD (Leaf et al., 2017; Reichow \& Volkmar, 2010). By implementing appropriate interventions targeting social development for children with autism, educators, caregivers and professionals, can collectively mitigate many of the sobering potential negative outcomes associated with social deficits. Our educational-psychological approach to social skills development is based on a 'continuum'perspective. Social and adaptive skills (skills relating to one's daily functioning in many domains) can be learned and improved gradually. By continuously refining educational measures and practices, we can strengthen social and adaptive skills of children with ASD.

\section{Social Competence - A Broad Construct}

Social competence is broad construct. One of the earlier studies on the concept of competence as a social-relevant construct was done by Thorndike (1927). Thorndike (1927) compared social competence to "social intelligence." White (1959) portrayed social competence as "an organism's capacity to interact effectively with its environment" (p. 297). O'Malley (1977) defined social competence as follows:

\begin{abstract}
productive and mutually satisfying interactions between a child and peers or adults. Productive interactions attain personal goals of the child, whether immediately or in the long run, which are adaptive in classroom settings. Interactions will be satisfying to the child when goals are attained, and to the others if actions in pursuit of the goals are received in either a benign or positive manner (p. 29).
\end{abstract}

O'Malley (1977) provides three reasons for studying social competence:

1. Social or interpersonal competence is a necessity for participation in society.

2. Social competence is associated with greater academic success.

3. Social competence is comprised of essential interrelated components.

In his studies of social or ecological factors that have an impact on the socialization of children and adolescents, learning and development, Garbarino (1985) defines socially relevant competence as:

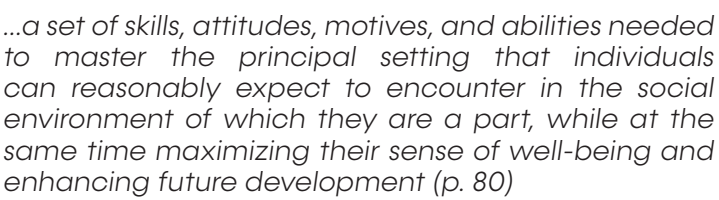

Garbarino argues further that competence is "...the ability to succeed in the world" and that it must be "the goal of socialization and development" (p. 81). In the following years, Garbarino's concept of 'social competence' garnered critical importance (Ogden \& Hagen, 2019). In line with Garbarino's views of social competence, Guralnick (1990) proposed that social competence is an important ability "of young children to successfully and appropriately select and carry out their interpersonal goals" (p. 4). Social competence has been described as the knowledge and skills which persons develop in order to deal effectively with life's many choices, challenges, and opportunities (Han \& Kemple, 2006; Leffert et al., 1997).

Many other researchers proport that satisfying and effective social interactions are the core component social competence. Katz and Mcclellan (1997) describe socially competent young children as "those who engage in satisfying interactions and activities with adults and peers" (p. 1). Similarly, Schneider (1993) viewed social competence as relational competence: 
"the ability to implement developmentally-appropriate social behaviors that enhance one's interpersonal relationships without causing harm to another" (p. 19). These types of interpersonal relationships necessitate social skills that ensure a person's appropriate "emotional responses to others" (Clausen, 1991, p. 808). Han and Kemple (2006) emphasized that, "Social competence is indexed by effectiveness and appropriateness in human interaction and relationships" (p. 241). Gresham and his colleagues (Gresham et al., 2001) defined social competence as, "The degree to which students are able to establish and maintain satisfactory interpersonal relationships, gain peer acceptance, establish and maintain friendships, and terminate negative or pernicious interpersonal relationships" (p.331). Orpinas (2010) also views social competence as the ability to handle social interactions effectively. According to Orpinas (2010, p. 1923), social competence refers to "(a) getting along well with others, (b) being able to form and maintain close relationships, and (c) responding in adaptive ways in social settings."

Orpinas (2010) viewed social competence as a product of cognitive abilities, emotional processing, behavioral skills, social awareness and family and cultural values regarding interpersonal relationships.

As social competence involves such a broad set of skills and knowledge, some researchers describe the concept as ambiguous (Nangle et al., 2010). McFall (1982) elaborated that the term social competence has become so ubiquitous that it "strains our credibility and arouses our suspicions" (p. 2). Despite the various descriptions of social competence, researchers still judiciously distinguish social competence from social skills (Dodge \& Murphy, 1984; McFall, 1982). Social competence refers to an evaluative judgement by outside observers as to the adequacy of performance in a social task, whereas "social skills refer to the specific abilities or behaviors that allow for effective responding in a social task" (Nangle et al., 2010, p. 6). Walker et al. (2004) explained, succinctly, that social skills refer to specific behaviors while social competence refers to judgments from others of one's social proficiency. Still others describe social skills as the precursor, the necessary prerequisite components, of social competence (Gresham, 1986).

\section{Adaptive Behavior and Skills}

In his early conceptualization of social competence Gresham (1986) suggested that social competence was comprised of three subdomains: (a) adaptive behavior, (b) social skills, and (c) peer acceptance. According to Whitcomb (2018), social skills are necessary for the development of adaptive behavior. The American Association on Intellectual and Developmental Disabilities (AAIDD, 2008, p. 2) considers adaptive behavior as "the conceptual, social, and practical skills that people have learned to be able to function in their everyday lives." Adaptive behaviors are dependent on the necessary skills for independent and responsible behavior which is appropriate in a given cultural context. Several researchers relate adaptive behaviors to functional living skills. In addition to 'functional living skills' or 'adaptive skills', these skills are also known as 'skills for self-help' and 'practical life skills' where the main intention of developing these skills is to maximize the capacity of an individual for safe independent living. The possession of rudimentary social skills is crucial for the development of independent safety skills. For example, if one is lost in an unfamiliar city without a map or cell phone, one would need to know how to appropriately ask another individual for directions. Therefore, safety skills and social skills are often considered to be entwined. According to Özerk and Özerk (2020) the following skills are important in daily functioning:

\begin{tabular}{ll}
\hline -Identify the address, phone & \\
number, buses, trains and/or & -Follow safety rules \\
subways for traveling in and & -Read and follow safety signs \\
out of the community & -Use menus to order meals \\
-Locate public bathrooms to & -Raise and care for \\
use for washing and toileting & flowers/houseplants \\
-Carry identification in the & -Raise and care for a pet \\
wallet & -Attend movies, concerts and \\
-Follow pedestrian signs and & plays \\
conventions. & -Plan and participate in \\
-Be able to use appropriate & picnics, excursions, etc. \\
transportation. & -Be aware of social distance \\
-Visit relatives, friends and & and respect personal space \\
neighbors & \\
\hline
\end{tabular}

As we expand upon the construct of social skills, the interconnectedness of social competence, adaptive skills and social skills will become more apparent.

\section{Social Skills}

Gresham and colleagues (2006) asserted, "Social skills represent a set of competencies that (1) facilitate initiating and maintaining positive social relationships, (2) contribute to peer acceptance and friendship development, (3) result in satisfactory school adjustment, and (4) allow individuals to cope with and adapt to the demands of the social environment" (p. 364). Gresham \& Elliot (1990) further proposed that social skills involved five dimensions: Cooperation, assertion, responsibility, empathy, and self-control. These dimensions comprise the well-known social skills rating scale system Social Skills Rating System (SSRS) and revised Social Skills Improvement System (SSIS), and can be described as follows:

Cooperation: An important aspect of cooperation is to follow rules and messages. Collaboration involves sharing, helping others and being interdependent. Cooperation should be practiced in realistic contexts, and it must be valued and actively pursued. 
Assertion: The ability to assert oneself is often crucial to being able to participate actively in social communities. This also includes the ability to say no to what you, for example, should preferably not participate in. Assertion includes asking others for help, being able to stand for something yourself and reacting to the actions of others.

Responsibility: Responsibility is about perfor-ming tasks and showing respect for one's own and others' assets and work. Development of responsibility will be related to gaining responsibility through co-determination and taking the consequences of responsibility. Responsibility is also about the ability to communicate with adults.

Empathy: It is important in order to establish friendships and close relationships with others, and will also act as a counterweight to, for example, bullying and violence. Empathy is situational and can therefore be developed and changed. If students are to develop empathy, they should meet empathic friends and teachers.

Self-control: Self-control is about adapting to the community and taking others into account. It means being able to wait your turn, be compromiseFigure 1

Lamer Social Competence in Preschool Scale (LSCIP)

\begin{tabular}{|c|c|}
\hline $\begin{array}{l}\text { AREA OF SOCIAL } \\
\text { COMPEIINOE }\end{array}$ & COMPRISING SOCIAL SKILLS \\
\hline Assertiveness & $\begin{array}{l}\text { 1. Initiates contact (in an OK manner) } \\
\text { 2. Wants to participate in play or other group activities. } \\
\text { 3. Speaks when several others are present (in an OK manner) } \\
\text { 4. On his/her own initiative joins other children's play or activities. } \\
\text { 5. Meets new people with openness, makes eye contact. } \\
\text { 6. Initiates play. } \\
\text { 7. Involves him/herself completely in social role play. } \\
\text { 8. Makes friends easily }\end{array}$ \\
\hline Self-Control & $\begin{array}{l}\text { 1. Accepts that his/her wishes will not always be fulfilled. } \\
\text { 2. Waits for his/her turn in games and other activities. } \\
\text { 3. Can control anger in conflicts with other children. } \\
\text { 4.. Compromises in conflict situations (e.g., by changing own opinions or } \\
\text { adjusting own wishes) } \\
\text { 6. Can control his/her anger in conflict with adults. } \\
\text { 7. Can share toys and stuff with others }\end{array}$ \\
\hline Empathy and Role-taking & $\begin{array}{l}\text { 1. Shows that he/she sees that others are happy. } \\
\text { 2. Shows that he/she sees that others are sad. } \\
\text { 3. Shows that he/she sees that others are angry. } \\
\text { 4. Shows that he/she sees others are afraid. } \\
\text { 5. Recognizes, and can express in words, others' feelings }\end{array}$ \\
\hline Prosocial Behavior & $\begin{array}{l}\text { 1. Helps other children without being asked. } \\
\text { 2. Helps you without being asked. } \\
\text { 3. Supports and encourages other children. } \\
\text { 4. Helps other children in conflict situations. } \\
\text { 5. Says something nice, gives compliments to other children }\end{array}$ \\
\hline Adjustment & $\begin{array}{l}\text { 1. Does as he/she is asked. } \\
\text { 2. Completes tasks he/she is assigned. } \\
\text { 3. Completes tasks he/she is given within the designated time. } \\
\text { 4. Cleans up after him/herself when play/activities are terminated }\end{array}$ \\
\hline Fairness & $\begin{array}{l}\text { 1. Reacts critically to rules that are perceived as unfair. } \\
\text { 2. Can resist group pressure. } \\
\text { 3. Speaks out clearly when he/she conceives something as unfair }\end{array}$ \\
\hline
\end{tabular}

oriented and respond to teasing and comments from others without retaliating, getting angry or fighting. Awareness of one's own feelings and ability to understand oneself is essential here.

Norwegian preschool researcher Kari Lamer (1997), inspired by Gresham and Elliot's (1990) Social Skills Rating System (SSRS), developed the Lamer Social Competence in Preschool Scale (LSCIP). Later in 2006, Lamer (2006) categorized social competence into six areas: (1) Assertiveness (2) Self-control, (3) Empathy and role-taking, (4) Prosocial behavior, (5) Adjustment, and (6) Fairness. The following figure (Figure 1) shows the socials skills necessary for the development of social competence in preschool children.

A comprehensive evaluation of the Lamer Social Competence in Preschool Scale (Løkken et al., 2018) revealed that LSCIP is a valuable tool to be used to monitor children's development of social competence. However, the researchers also found that in preschools, the domain of Play, joy and humor should not be considered separate dimensions as play activities require literally all dimensions of social competence" (Løkken et al. 2018, p. 13). Løkken et al (2018) added Fairness as a separate dimension of social competence and described fairness of being 
comprised of the following social skills: reacting critically to rules that are perceived as unfair, resisting group pressure, and speaking out clearly when he/ she conceives something as unfair.

Several researchers (Caldarella \& Merrell, 1997; Gresham, Sugai, \& Horner, 2001) propose the following dimensions of social skills depicted below:

\section{Figure 2.}

Five Dimensions of Social Skills (Based on the works of Caldarella \& Merrell, 1997, p. 264-278; Gresham, Sugai, \& Horner, 2001, p. 333-334).

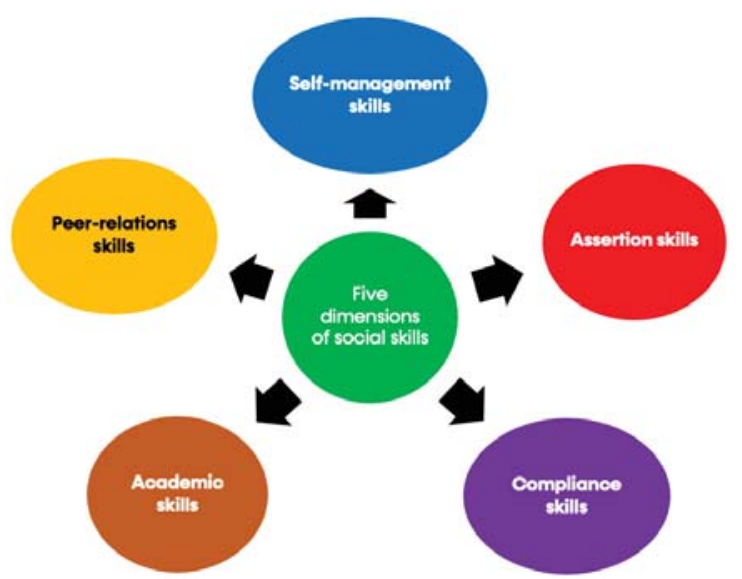

The five dimensions can be described as follows:

Peer relations skills include complimenting others, offering help, inviting others to interact, being sought out by others, turn taking, and exhibiting leadership ability, empathy, has many friends, stands up for others, sense of humor.

Self-management skills include controlling one's temper, following rules, compromising in conflict situations, accepting criticism, cooperating with others, organizing, and ignoring criticism and distraction.

Assertion skills include initiating conversations, acknowledging compliments, inviting peers to play, displaying self-confidence and selfadvocacy, making friends, expressing feels and joining in ongoing activities with others.

Compliant skills include following directions, following rules, using free time appropriately, sharing with others, responding appropriately to criticism, finishing tasks, keeping things clean, and putting things away.

Academic skills include completing work independently, listening to teacher directions, following academic directions, displaying appropriate work habits, producing acceptable work, maintaining time on task, and using free time advantageously.

Elliott and Gresham (2007) asked teachers (kindergarten, preschool, elementary and middle school) to rate more than 80 social skills on a 3-point scale ( 0 = not important, 1 = important, 2 = critical). Teachers identified the following 10 social skills as being the most critical social skills for classroom success:

1. Listens to others,

2. Follows directions,

3. Follows the rules,

4. Ignores peer distractions,

5. Asks for help,

6. Takes turns in conversations,

7. Cooperates with others,

8. Controls temper in conflict situations,

9. Acts responsibly when with others, and

10. Shows kindness to others

Other researchers describe the following skills as the key components of social skills:
-showing an interest in others,
-participate in group play and organized group activities,
-initiating social interaction,
-accepting others initiative to social interaction, -sustaining interactions,

-responding appropriately to peers' inappropriate behaviors, and

-be able to contribute to solve social problem (Odom et al., 1999; Jamison et al., 2012).

Social skills are critical for the development of positive relationships with peers, "which satisfy the need to belong, protect against victimization, and promote cognitive and social development" (Szumski et al., 2019 p. 2823). Human beings utilize and require social skills to communicate, interact and socialize with each other. We humans conduct our social interaction verbally and non-verbally. We use body language, eye contact, facial expressions, words, gestures, and several body movements to communicate out thoughts, feelings, desires, and dislikes. Social skills enable us to make friends, to collaborate, to cooperate and to learn. Adequate social skills are required to successfully meet our needs in appropriate ways. Well-developed and well-practiced social skills help us to establish harmonious relationship with others around us. We use our social skills to clarify disagreements and manage relationships. We accomplish tasks, provide mutual support, and expand our social networks by the reliance on social skills.

Appropriate social and adaptive skills (listening, eyecontact, sharing, turn taking, empathy, cooperation, collaboration, compliance, initiation, following the rules, functional communication, inclusion, helping each other, solving problem together, handling conflicts together etc.) can result in the following: 
a) improved social-awareness and healthier peer relationships

b) improved perspective taking skills and improved empathy

c) increased social acceptance and higher quality of friendships

d) increased learning opportunities

e) increased capability to better personal hygiene

f) heightened self-care and safety skills

g) reduced stress

h) greater success in school (Silveira-Zaldivar 2019; Silveira-Zaldivar \& Cortis, 2019)

Early, intensive, and continuous interventions by competent practitioners are important when focusing on teaching of children with ASD (Howlin et. al., 2009; Klintwall \& Eikeseth, 2014; Rogers \& Dawson, 2010). A study conducted by Jones, Greenberg and Crowley (2015) revealed that five-year-old children who displayed positive social skills, such as listening, sharing, cooperation and following of rules, were more likely to attend higher education and obtain a full-time job in early adulthood. Hence, targeting social skills interventions for children who present with social deficits is critical for their success in many life domains.

\section{Evidence-Based Practices for the Development of Social Skills for Children with Autism}

Social skills deficits are commonly described as comprising of two categories: skill acquisition deficits and skill performance deficits. Acquisition deficits refer to skills that a student has yet to develop - skills that are not currently in an individual's repertoire. Performance deficits refer to skills that an individual possesses, but that are not consistently or appropriately implemented. To be most effective, social skills interventions for children with autism should be tailored to the type of deficit (performance or acquisition) that the child is exhibiting. Furthermore, researchers suggest that interventions for children with autism, should target and develop behaviors that are socially valid (Elliott et al., 2008). Socially valid behaviors can be described as, "...those behaviors that society considers important, encourages, and reinforces" (Gresham \& Elliottt, 2014, p. 159). Fortunately, several evidence-based social skills interventions have been developed to enhance the development and successful implementation of social skills, bolster social competence, and perpetuate socially valid behaviors (Gresham, 2016; Reichow \& Volkmar, 2010; Whalon et al. 2015). Furthermore, evidence-based programs have been designed to specifically target the social skills of individuals with autism. Wolstencroft et al. (2018) conducted a systematic review of group social skills interventions for children with high functioning autism, focusing on studies that included the parent-report Social Responsiveness Scale (SRS) as the criterion for success. The results of the meta-analysis of 10 studies showed improvement in the overall SRS score, as well as an increase in the social communication SRS subscale and reductions in the reduced restricted interests and repetitive behaviors subscales (Wolstencroft et al., 2018). The utilization of evidence-based social skills programs provides a means to effectively address the inherent social skills deficits of individuals with autism. White and Keonig (2007) reviewed studies of group social skills interventions between 1985 and 2006 and identified several effective strategies for teaching social skills training for children with ASD. A summary of White and Koenig's findings is depicted in Figure 3.

A recent comprehensive study by the National Clearinghouse on Autism Evidence and Practice (Steinbrenner et al., 2020) identified the following 26 social skills evidence-based practices for children, youth, and young adults with autism (see Figure 3).

All of the mentioned 26 methods, practices, and procedures have demonstrated a positive effect on the development of social skills for individuals with ASD. The abbreviations DRA, DRI and DRO stand respectively for Differential Reinforcement of Alternative behaviors, Differential Reinforcement of Incompatible behaviors and Differential Reinforcement of Other behaviors. PRT refers to Pivotal Response Training. As the table suggests, some EBPs for social skills are more valid for a particular age group than other EBPs. While several EBPs exist specifically for students with autism to enhance social skills development, the Frank Porter Graham Child Development Institute, at UNC-Chapel Hill (Wong et al., 2015) suggest that some of the most effective and most widely utilized programs to enhance social competence include: peer mediated interventions (PMI), social narratives, social skills training (SST), structured play group (SPG), Pivotal Response Training (PRT), and video modeling (VM).

\section{Peer Mediation Interventions}

Since more students with autism now spend more time in regular education inclusive settings with their typical peers than ever before, it would be beneficial for educators to concentrate on ways to facilitate and enhance social interaction between students with ASD and their typical peers, especially since research has demonstrate that interaction between these two groups tends to be limited naturally (Chamberlain et al., 2007; Humphrey \& Symes, 2013). Peer Mediated Interventions have demonstrated efficacy in enhancing the social skills of students with autism (such as peer initiation, frequency and length of peer responses, and the quality of peer interaction) as well as academic time on task, reading comprehension, and communication 
Figure 3

Goals for Promising Social Skills Interventions and Promising Teaching Strategies

\begin{tabular}{|c|c|}
\hline \multicolumn{2}{|c|}{$\begin{array}{l}\text { GOAL FOR PROMISING SOCIAL SKILLS INTERVENTIONS: } \\
\text { Increase social motivation. }\end{array}$} \\
\hline $\begin{array}{l}\text { PROMISING TEACHING } \\
\text { STRATEGIES }\end{array}$ & $\begin{array}{l}\text {-Foster self-awareness and self-esteem } \\
\text {-Develop nurturing, fun environment } \\
\text {-Intersperse new skills with previously mastered -skills } \\
\text {-Start with simple, easily learned skills (errorless teaching) }\end{array}$ \\
\hline \multicolumn{2}{|r|}{$\begin{array}{l}\text { COAL FOR PROMISINC SOCIAL SKILLS INTERVENTIONS: } \\
\text { Increase sociol initiations. }\end{array}$} \\
\hline $\begin{array}{l}\text { PROMISING TEACHING } \\
\text { STRATECIES }\end{array}$ & $\begin{array}{l}\text {-Make social rules clear and concrete (e.g., stay one arm's length from } \\
\text { another person) } \\
\text {-Model age-appropriate initiation strategies } \\
\text {-Use natural reinforcers for social initiations (e.g., follow child's } \\
\text { conversation lead/interest) } \\
\text {-Teach simple social 'scripts' for common situations }\end{array}$ \\
\hline \multicolumn{2}{|c|}{$\begin{array}{l}\text { GOAL FOR PROMISING SOCIAL SKILLS INTERVENTIONS: } \\
\text { Improve appropriate social responding. }\end{array}$} \\
\hline $\begin{array}{l}\text { PROMISING TEACHING } \\
\text { STRATEGIES }\end{array}$ & $\begin{array}{l}\text {-Teach social response scripts } \\
\text {-Reinforce response attempts } \\
\text {-Use modeling and role-play to teach skills }\end{array}$ \\
\hline \multicolumn{2}{|r|}{$\begin{array}{l}\text { GOAL FOR PROMISING SOCIAL SKILLS INTERVENTIONS: } \\
\text { Reduce interfering behaviors }\end{array}$} \\
\hline $\begin{array}{l}\text { PROMISING TEACHING } \\
\text { STRATEGIES }\end{array}$ & $\begin{array}{l}\text {-Make teaching structured \& predictable } \\
\text {-Differentially reinforce positive behaviors } \\
\text {-Keep behavior charts (e.g., checkmarks or stars) for positive behavior } \\
\text {-Review socially appropriate and inappropriate behaviors of the } \\
\text { participants as a group, via video or audiotape segments }\end{array}$ \\
\hline \multicolumn{2}{|c|}{$\begin{array}{l}\text { COAL FOR PROMISING SOCIAL SKILLS INTERVENTIONS: } \\
\text { Promote skill generolizetion }\end{array}$} \\
\hline $\begin{array}{l}\text { PROMISING TEAOHING } \\
\text { STRATECIES }\end{array}$ & $\begin{array}{l}\text {-Orchestrate peer involvement (e.g., prompting \& initiating social } \\
\text { interactions, physical proximity) } \\
\text {-Use multiple trainers \& individuals with which to practice skills } \\
\text {-Involve parents in training } \\
\text {-Provide opportunities to practice skills in safe, natural settings (e.g., field } \\
\text { trips) } \\
\text {-Use time between session to practice skills (e.g., via homework') }\end{array}$ \\
\hline
\end{tabular}

(Chang \& Locke, 2016; Cole \& McCurdy, 2014; Kasari et al., 2012; Rodríguez-Medina et al., 2016; Wolfberg et al., 2015; Zagona \& Mastergeorge, 2016). Many researchers consider the PMl essential components of modeling, prompting, and reinforcement to be the most successful procedures for teaching social skills and enhancing social competence (Cole \& McCurdy, 2014; Kamps et al., 2015). Whalon et al. (2015) critically reviewed 37 school based single-case design studies involving more than 105 children ages three to 12 and found that, "peer-mediated, multicomponent, adult-mediated interventions garnered more evidence for the promotion of peer interactions in school settings than other interventions" (p. 1528). Students with ASD who benefit the most from PMI interventions, share certain characteristics, such as average cognition, interest in peer interaction, and compliant behavior (Chang \& Locke, 2016). In addition to their peers with autism, typical peers also benefit from PMl interventions (Kamps et al., 2015; Schlieder et al., 2014). Typical peers who participate in PMI programs have demonstrated enhanced social skills of their own including higher quality friendships, a greater understanding of their peers with autism, and reduced feelings of isolation (Locke et al., 2012). One of the benefits of PMl interventions is that PMI interventions can be implemented successfully in short periods of time and in a variety of settings, such as small groups, play periods such as recess, via whole class intervention, or after school programs (Chang \& Locke, 2016; Corbett et al., 2015; Zagona \& Mastergeorge, 2016). Kasari et al., 2012) achieved positive social outcomes for students with autism in a PMI intervention implemented just twice a week for 20-minute sessions over only six weeks (12 sessions total). Some research has indicated that recess interventions allow for greater maintenance and generalization of skills than interventions implemented in other settings. Peer-Mediated Intervention (PMI) at recess or lunch has been demonstrated to increase social interaction skills as well as reduce negative, inappropriate behaviors (Harper, Symon, \& Frea, 2008; Rodríguez-Medina et al., 2016; Zagona \& Mastergeorge, 2016). Some PMI unstructured activities capitalize on the student with autism's interests for success (Koegel et al., 2013). Additional optional components to the 
Figure 4

The Age Groups that EBP with Positive Impact on Social Skills

\begin{tabular}{|c|c|c|c|c|c|c|}
\hline \multirow[b]{2}{*}{$\begin{array}{c}\text { Evidence-Based } \\
\text { Methods, Practices/ and } \\
\text { Procedures }\end{array}$} & \multicolumn{6}{|c|}{$\begin{array}{c}\text { SOOIAL SKILLS } \\
\text { (Skills needed to intercot with others) }\end{array}$} \\
\hline & 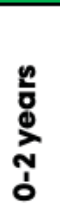 & 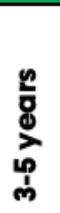 & $\frac{n}{\frac{n}{2}}$ & 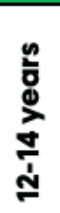 & 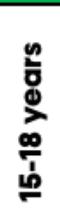 & 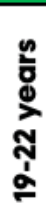 \\
\hline \multicolumn{7}{|l|}{ Antecedent-Based Intervention } \\
\hline \multicolumn{7}{|l|}{$\begin{array}{l}\text { Augmentative and Alternative } \\
\text { Communication }\end{array}$} \\
\hline \multicolumn{7}{|l|}{$\begin{array}{l}\text { Behavioral Momentum } \\
\text { Intervention }\end{array}$} \\
\hline \multicolumn{7}{|l|}{$\begin{array}{l}\text { Cognitive Behavioral/ } \\
\text { Instructional Strategies }\end{array}$} \\
\hline \multicolumn{7}{|l|}{ DRA, DRI and DRO } \\
\hline \multicolumn{7}{|l|}{ Discrete Trial Training } \\
\hline \multicolumn{7}{|l|}{ Exercise and Movement } \\
\hline \multicolumn{7}{|l|}{ Extinction } \\
\hline \multicolumn{7}{|l|}{$\begin{array}{l}\text { Functional Communication } \\
\text { Training }\end{array}$} \\
\hline \multicolumn{7}{|l|}{ Modeling } \\
\hline \multicolumn{7}{|l|}{ Music-Mediated Intervention } \\
\hline \multicolumn{7}{|l|}{ Naturalistic Intervention/PRT } \\
\hline \multicolumn{7}{|l|}{$\begin{array}{l}\text { Parent-Implemented } \\
\text { Intervention }\end{array}$} \\
\hline \multicolumn{7}{|l|}{$\begin{array}{l}\text { Peer-Based Instruction and } \\
\text { Intervention }\end{array}$} \\
\hline \multicolumn{7}{|l|}{ Prompting } \\
\hline \multicolumn{7}{|l|}{ Reinforcement } \\
\hline \multicolumn{7}{|l|}{$\begin{array}{l}\text { Response Interruption/ } \\
\text { Redirection }\end{array}$} \\
\hline \multicolumn{7}{|l|}{ Self-Management } \\
\hline \multicolumn{7}{|l|}{ Sensory Integration ${ }^{\infty}$} \\
\hline \multicolumn{7}{|l|}{$\begin{array}{l}\text { Social Narratives /Social } \\
\text { Stories }^{\mathrm{TM}}\end{array}$} \\
\hline \multicolumn{7}{|l|}{ Social Skills Training / PEERS ${ }^{\oplus}$} \\
\hline \multicolumn{7}{|l|}{ Task Analysis } \\
\hline \multicolumn{7}{|l|}{$\begin{array}{l}\text { Technology-Aided Instruction } \\
\text { and Intervention }\end{array}$} \\
\hline \multicolumn{7}{|l|}{ Time Delay } \\
\hline \multicolumn{7}{|l|}{ Video Modeling } \\
\hline Visual Supports & & & & & & \\
\hline
\end{tabular}

PMI recess/lunch package include direct instruction of social skills, token-economy, priming and/or group contingencies (McFadden et al., 2014).

Pivotal Response Training

Pivotal Response Training (PRT) is a comprehensive intervention package for students with autism targeting "pivotal behaviors" include motivation, initiation, initiation of social interaction, self-management, and understanding and utilizing multiple environmental cues (Koegel \& Koegel, 2006; Schriebman et al., 1996). The PRT technique is child-centered - yet adultfacilitated, and PRT utilizes applied behavior analysis (ABA) procedures to provide support in naturalistic settings (Koegel \& Koegel, 2006; Platos \& Wojaczek, 2017). PRT has been demonstrated to be effective in enhancing and augmenting social skills and functional communication (Cadogan \& McCrimmon, 2015; Koegel et al., 2014). PRT can be utilized in the classroom, home, community, and/or recreational 
settings such as lunch/recess. PRT typically involves an experienced trainer working in a 1:1 capacity with a focus student in the natural setting to promote and enhance those pivotal behaviors. Interventionists implementing PRT utilize the student's natural interests and preferences to trigger learning.

\section{Social Skills Group Training}

Social skills group training (SSGT) is the most commonly utilized school intervention for children with autism. SSGT typically involve several students of similar ages participating in a small group setting with a trained adult facilitator, such as a teacher, counselor, or speech therapist, or behaviorist. An adult facilitator tends to guide the participants to interact. Social skills groups conducted in the school setting can be classified into three types: (a) skills based (didactic instruction provided by an adult facilitator); (b) engagement based (peers engage in one another in play and/or constructive projects, such as building Legos); and (c) mixed (a combination of direct didactic instruction followed by a period of active peer engagement). Didactic models often involve instruction, modeling, practice, and feedback. Engagement groups (such as those employing $\mathrm{PMI}$ ) tend to capitalize on shared interest between children at schools (Koegel et al., 2013; Wolfberg et al., 2015). Some SSGT involve homework with the goal of enhancing skill generalization. SSGT topics include such activities as giving a compliment to another, asking for help, greeting others, initiating, and sustaining a conversation. Ongoing collaboration with a parent and/or teacher and behavior monitoring is often key to the success of a solid SSGT. Meta-analysis of the use of SSGTs with students with autism have showed promising positive gains in social skills (Gates, Kang, \& Lerner, 2017).

LEGO therapy (LeGoff, 2004) is a research based SSGT for youth that uses Legos to increase social competence in a structured environment in which the participants are assigned clearly defined roles and share an interest in Legos. Lego Therapy has demonstrated efficacy with students with autism as well as student with other conditions, such as attention deficit hyperactivity disorder (ADHD). LEGO club therapy originated using typical peers as models in the group. Lego Club Therapy is research demonstrated to enhance friendship making skills, peer social interaction, peer to peer communication and problem-solving skills (Owens et al., 2008). LEGO therapy is designed to be administered twice a week for ten weeks for approximately 45 minutes to an hour, but the program allows for flexibility in both time and settings. While originally designed for students age seven and up, students as young as kindergarten age have benefited from the program.

The Program for the Education and Enrichment of
Relational Skills (PEERS) is an evidence- based SSGT program specifically designed to enhance social interaction skills for individuals with autism (Laugeson, 2014). The PEERS program expands the foundation of the Children's Friendship Training (CFT) (Frankel and Myatt, 2003). The primary aim of the PEERS program is to enhance the friendship making skills of individuals with autism. Currently, the PEERS program includes a preschool program, an adolescent program, and a young adult program. Of seventy-three middle school students with ASD along with their parents and teachers who participated in one of the adolescent PEER program for 14 weeks, the PEERS treatment group significantly improved social functioning in the areas of teacher-reported "social responsiveness, social communication, social motivation, social awareness, and decreased autistic mannerisms, with a trend toward improved social cognition on the Social Responsiveness Scale." (Laugerson, 2014, p. 1). Since its debut, the PEERS program has expanded to over 80 countries worldwide and over a dozen foreign languages. Furthermore, the program has demonstrated utility in improving the social skills of individuals with other conditions, such as ADHD and/ or anxiety disorders (Laugeson, 2012). PEERS has been developing an online delivery model in addition to the traditional in person delivery. The PEERS program is comprised of the following essential components: a) relevant portions of social skills curriculum; (b) the use of parent-assistance (or other designated individual acting as a coach); and (c) structural elements of the lesson format (Laugeson et al., 2009, 2010).

\section{Positive Behavior Reinforcement Interventions}

Positive Behavior Reinforcement Interventions are the most-commonly used strategy for reducing maladaptive behaviors and increasing appropriate pro social behaviors (Matson \& Boisjoli, 2008). Adding positive behavior interventions to other evidence-based social skills interventions (such as peer mediated interventions or video modeling), has been demonstrated to increase the efficacy of those programs (Camargo et al., 2014; Mason et al.,2012). Positive reinforcement is the presentation of a stimulus, such as a tangible object, a token, or verbal praise, immediately after a behavior, which then increases the likelihood that the behavior will recur (Cooper et al., 2007). Variations of delivering positive reinforcement include the use of token economies, differential reinforcement of other behaviors (DRO) reinforcing a child for going periods of time without engaging in a particular maladaptive behavior target; and differential reinforcement of alternative behaviors (DRA) - reinforcing for alternative behaviors that are more socially appropriate and meet the same function of the maladaptive behavior (such as reinforcing a child for asking for a break when he desires to escape an unpleasant situation as opposed 


\section{iejee}

to engaging in a tantrum when presented with the unpleasant stimuli) (Cooper et al., 2007).

\section{Social Narratives}

Social narratives are one of the most widely utilized and researched methods for the enhancement of social skills. The concept of social narratives is derived from the well-known intervention strategy of Social Stories $^{\text {TM }}$ developed by Carol Gray in 1993. Social Stories $^{\text {TM }}$ (Gray et al., 1993) are short, personal stories, written in the first person to teach children with autism how to navigate a challenging social situation. Social stories are most beneficial for students with autism to reduce a targeted problem behavior or to inform children of an effective social response (Gray, 2010, 2021; Hutchins \& Prelock, 2013; Pane et al., 2015). As such, social stories are often used as a supplemental program or within a broader social skills intervention package for enhancing social skills (Kokina \& Kern, 2010). Carol Gray is in the process of releasing Social Stories 10.3, the fourth version of the Social Story Criteria. Carol Gray defines. Social Stories ${ }^{\mathrm{TM}} 10.3$ as follows:

Recognizing that every human experience and perspective is unique and valid, and that social impairments and their solutions are shared, a Social Story accurately describes a personally relevant topic (often a context, skill, achievement, or concept) according to ten defining criteria. These criteria guide Story research, development, and implementation to ensure an overall patient and supportive quality and a format, voice, content, and learning experience that is descriptive, meaningful, respectful, and physically, socially, and emotionally safe for the Story audience (a child, adolescent, or adult). (Gray, 2021, p. 19, power point handout).

Gray (2004) has recommended that all social stories include a variety of descriptive, perspective, affirmative and cooperative sentences, for every directive or control sentence. While a variety of individuals may author social stories (i.e., parents, teachers, psychologists, daycare providers, behavior therapists, etc.), parent involvement is essential for a story to be considered a valid Social Story ${ }^{\mathrm{TM}}$ (Gray, 2021). To develop a successful social story, authors consider external and internal contexts and their interaction (Gray, 2021). Social narratives are primarily designed for those with reading skills, but individuals with limited decoding skills but strong auditory comprehension skills may also benefit (Gray, 2010). Social stories may incorporate visuals to augment social comprehension. Social stories are most effective when implemented appropriately and with fidelity by trained personnel (Mayton et al., 2013).

\section{Video Modeling}

Research suggests that video modeling is as effective as peer mediation in enhancing social skills (Wang et al., 2011). Video Modeling is particularly effective for teaching novel social behavior (Charlop-Christy, Le, \& Freeman, 2000; Plavnick et al., 2015). Video modeling may be implemented formally via a structured program or informally by a provider to a targeted student. Video modeling requires little adult support or direction (Hume et al., 2009) - making it a convenient intervention choice for schools. Indirectly, video modeling incorporates elements of peer mediation and modeling. Social skills trainings are delivered in a form that is comfortable and attractive to children: children watch videos of expected and/or desired behavioral scenarios and then practice the behavior themselves.

While the National Clearinghouse on Autism Evidence and Practice (Steinbrenner, et al.,2020) has been integral in identifying EBPs designed to enhance the social functioning of students with autism, two additional resources are available in the United States to help educators find evidence-based social skills training suitable to meet the needs of their setting: The Collaborative for Academic, Social, and Emotional Learning (CASEL) group and the Positive Environment Network of Trainers (PENT). (CASEL was formed in 2003 to establish evidence-based SEL practices in the public-school setting (Schonert-Reichl \& Hymel, 2007). The CASEL guide for evidence-based social emotional practices has been revised several times since 2003, with the most recent revision in 2013. The 2013 CASEL Guide provides information on 23 select social skills programs spanning preschool to high school. CASEL researchers (CASEL, 2013) have asserted that global social emotional learning enhances academic achievement and behavior, while simultaneously reducing maladaptive behaviors and emotional difficulties. The PENT association, with the support of the Renowned Educational Psychologist and Behavior Psychologist Dr. Clayton Cook, (2015) distinguishes between interventions for skill deficits and interventions for performance deficits. Dr. Cook (2015) has recommended the following evidencebased social skills training program for students who present with deficits in social skills (Figure 5).

\section{Next Steps}

Despite the availability of many diverse evidencebased Social Skills interventions, many are not utilized by educators in the public-school settings (Locke et al., 2016; Owens et al., 2014; Stahmer et al.,2015) and/ or they are not utilized with efficacy (Deris \& Di Carlo, 2013; Kasari \& Smith, 2013). A review from 2007 that included 14 studies on SSGT highlighted the following research challenges: small sample size in studies, inadequate measurement tools for social functioning, and the need for various improvements (Williams et al., 2007). Furthermore, the literature gap illuminates 


\section{Figure 5}

Training Programs for Students with Deficits in Social Skills (Cook, 2015)

\begin{tabular}{|l|l|}
\hline \multicolumn{1}{|c|}{ CURRICULUM } & \multicolumn{1}{c|}{ AUTHORS/MAKERS } \\
\hline Skillstreaming & Arnold Goldstein and Ellen McGinnis (http://www.skillstreaming.com) \\
\hline PEERS & $\begin{array}{l}\text { Elizabeth Lqugessn http://www.semel.ucla.edu/peers \& } \\
\text { http://www.amazon.com/The-PEERS-Curriculum-School- } \\
\text { Based-Professionals/dp/041562696X }\end{array}$ \\
\hline $\begin{array}{l}\text { The Social Skills } \\
\text { System- } \\
\text { Intervention } \\
\text { Guide }\end{array}$ & $\begin{array}{l}\text { Frank Gresham and Stephen Elliott } \\
\text { http://www.pearsonclinical.com/psychology/products/100 } \\
\text { 000355/social-skills-improvement-system-ssisintervention- } \\
\text { guide.html }\end{array}$ \\
\hline $\begin{array}{l}\text { ACCEPTS } \\
\text { Program }\end{array}$ & $\begin{array}{l}\text { Hill A.Walker: http://www.proedinc.com/customer/productView.aspx?ID } \\
=62\end{array}$ \\
\hline $\begin{array}{l}\text { Prepare Program } \\
\text { Arnold Goldstein https://www.researchpress.com/books/818/preparecurriculum }\end{array}$ \\
\hline
\end{tabular}

that the generalizability social skills addressed during interventions has been neglected (Jonsson, et al., 2016; Kasari et al, 2014; Williams et al., 2007). In a recent study exploring the gap between educators and the successful implementation of evidence-based social skills interventions in the school setting, the researchers identified six key barriers: lack of training, lack of support, lack of time, prioritization conflicts, lack of resources, and staff mindset (Silveria-Zaldivar \& Curtis, 2019). To adequately address the critical need of those with autism to develop enhanced social skills, Carter et al. (2014) suggested five intervention areas:

1. Additional research should focus on social skills intervention that consider the functioning level of the individual.

2. Schools need to find ways to involve peers in interventions and to deliver interventions at school settings.

3. Peers and/or family members should be involved in interventions.

4. More technological based interventions should be explored, and

5. Research should create more appropriate social emotional assessments and interventions that focus primarily on the needs of an adolescent with autism.

Silveria-Zaldivar (2019) proposed the following suggestions for school districts to build the social competence of students with autism by implementing EBPs for social skills:

- Motivate administrators and other stakeholders to incorporate social skills in the school setting by sharing with them research regarding the relevance of the development of effective social skills.

- Increase education of evidence-based social emotional and behavioral practices in graduate school programs for educators and service providers, such as psychologists, counselors, and speech therapist.

○ Build a district team comprised of various stakeholders to model and teach school sites how to implement EBPs for students with autism.

o Increase and enhance training to all staff related evidence-based social skills interventions. Include direct modeling, practical experience, and field experience in the training.

- Offer parent training of EBPs to enhance the generalization of social skills.

o Consider the utilization of typical peers as agents of change.

o Increase collaborative opportunities amongst staff and stakeholders.

o Increase access to resources, sufficient personnel, and materials to implement for social skills.

o Incorporate the best-fit model (the consideration of cost, efficacy, and effort when determining the appropriate EBPs program or programs for a particular site or district).

o Have each school site develop a monitoring system to ensure that each student with autism on their campus has access to EBPs for social skills.

Addressing the social needs of students with autism in school settings is likely to yield advantages that exceed the students' school environment. The successful implementation of EBPs for social skills for students with autism will undoubtedly extend benefits to the society at large. 


\section{iejee $\sqrt{2}$}

\section{Conclusion}

This article sought to explain the constructs of social competence, social skills, and adaptive skills in a manner accessible and relatable to educators. Appropriate social skills are a prerequisite for social competence. Hence, successful interventions that improve social skills theoretically should improve social competency as well. Deficits in social skills have a profound and lasting impact on academic achievement, school behavior, social and emotional well-being including friendship and family relations, and adult outcomes for those with autism (Baumeister \& Leary, 1995; Kok et al., 2013; Seppala et al., 2013). Children with ASD have significant social skills impairments. Evidencebased social skills interventions are paramount in counteracting the negative effects of social deficits that are inherent in a diagnosis of autism. Social and adaptive skills are of pivotal nature. However, social, and adaptive skills are teachable and learnable skills. Children with ASD have difficulty learning these skills through natural social interaction without explicit guidance. Children with ASD require well-planned and well-implemented interventions to develop appropriate social and adaptive skills. Ultimately, the development of appropriate social and adaptive skills may be critical to the success of the individual with autism. Fortunately, there are more than two dozen evidence-based methods, practices, strategies, and procedures for improving social and adaptive skills of children with ASD. The challenge remains, however, in implementing those interventions for social skills in various settings and with regularity and fidelity.

\section{References}

American Association on Intellectual and Developmental Disabilities (2008). Frequently asked questions on intellectual disability and the AAIDD definition. Washington, DC: AAIDD Information.

American Psychiatric Association (APA) (2013). Diagnostic and Statistical Manual of Mental Disorders (DSM-5). Washington, D.C.: American Psychiatric Association.

Baron-Cohen, S. (1995). Mindblindness: an essay on autism and theory of mind. Boston, MA: MIT Press/Bradford Books

Baron-Cohen, S. (2001). Theory of mind in normal development and autism. Prisme, 34, 174-183.
Boujut, E., Dean, A., Grouselle, A., \& Cappe, E. (2016). Comparative study of teachers in regular schools and teachers in specialized schools in France, working with students with an autism spectrum disorder: Stress, social support, coping strategies and burnout. Journal of Autism and Developmental Disorders, 46(9), 2874-2889. doi:10.1007/s10803-016-2833-2

Baumeister, R., \& Leary, M. (1995). The need to belong: Desire for interpersonal attachments as a fundamental human motivation. Psychological Bulletin, 117(3), 497-529.

Berney, T. (2004). Asperger syndrome from childhood into adulthood. Advances in Psychiatric Treatment, 10, 341-351.

Brown, J. A., \& Mclntosh, K. (2012). Training, inclusion, and behaviour: Effect on student-teacher and student-SEA relationships for autistic students with autism spectrum disorders. Exceptionality Education International, 22(2), 77-88.

Caldarella, P. \& Merrell, K. (1997): Common dimensions of social skills of children and adolescents: A taxonomy of positive behaviors. School Psychology Review, 26(2), 264-278.

Calder, L., Hill, V., \& Pellicano, E. (2013). 'Sometimes I want to play by myself': Understanding what friendship means to children with autism in mainstream primary schools. Autism, 7(3), 296316.

Camargo, S. P., Rispoli, M., Ganz, J., Hong, E. R., Davis, H., \& Mason, R. (2014). A review of the quality of behaviorally based intervention research to improve social interaction skills of children with ASD in inclusive settings. Journal of Autism and Developmental Disorders, 44, 2096-2116. doi:10.1007/s10803-014-2060-7.

Carter, A. S., Davis, N. O., Klin, A., \& Volkmar, F. R. (2005). Social development in autism. Handbook of Autism and Pervasive Developmental Disorders, 1, 312-334.

Carter, E., Common, E., Sreckovic, M., Huber, H., Bottema-Beutel, K., Gustafson, J., Dykstra, J., ... Hume, K. (2014). Promoting social competence and peer relationships for adolescents with autism spectrum disorders. Remedial and Special Education, 35(2), 91-101. 
CASEL. (2013). Effective social and emotional learning programs. Retrieved from https://casel.org/wpcontent/uploads/2016/01/2013-casel-guide-1. pdf

Chamberlain, B., Kasari, C., \& Rotheram-Fuller, E. (2007). Involvement or isolation? The social networks of children with autism in regular classrooms. Autism and Developmental Disorders, 37(2), 23042.

Chang, Y-C., \& Locke, J. (2016). A systematic review of peer-mediated interventions for children with autism spectrum disorder. Research in Autism Spectrum Disorders, 27, 110. doi:10.1016/j. rasd.2016.03.010

Charlop-Christy, M.H., Le, L. and Freeman, K.A. (2000): A comparison of video modeling with in vivo modeling for teaching children with autism. Journal of Autism and Developmental Disorders, $30,537-552$

Cidav, Z., Marcus, S. C., \& Mandell, D. S. (2012). Implications of childhood autism for parental employment and earnings. Pediatrics, 129(4), 617-623. doi:10.1542/peds.2011-2700

Clausen,J. S. (1991). Adolescent Competence and the Shaping of the Life Course. American Journal of Sociology, 96(4), 805-842.

Cole, C., \& McCurdy, E. (2014). Use of a peer support intervention for promoting academic engagement of autistic students with autism in general education settings. Journal of Autism and Developmental Disorders, 44(4), 883-893. doi:10.1007/s10803-013-1941

Cook, A., Ogden, J., \& Winstone, N. (2017). Friendship motivations, challenges and the role of masking for girls with autism in contrasting school settings. European Journal of Special Needs Education, 32(4), 1-15. doi:10.1080/08856257.2017. 1312797

Cook, C. (2015). Group-Based Interventions for Student's with "Can't Do" Problems. Handouts presented at the Annual Conference of the Southern California PENT Cadre Members, San Bernardino, CA.

Cooper, J. O., Heron, T. E., \& Heward, W. L. (2007). Applied behavior analysis (2nd ed.). Upper Saddle River, NJ: Pearson.
Corbett, B. A., Key, A. P., Qualls, L., Fecteau, S., Newsom, C., Coke, C., \& Yoder, P. (2015). Improvement in social competence using a randomized trial of a theatre Intervention for children with autism spectrum disorder. Journal of Autism and Developmental Disorders, 46(2), 658-672. doi:10.1007/s10803-015-2600-9

Corona, L. L., Christodulu, K. V., \& Rinaldi, M. L. (2017). Investigation of school professionals' selfefficacy for working with students with ASD: Impact of prior experience, knowledge, and training. Journal of Positive Behavior Interventions, 19(2), 90-101.

Denham, S. A., \& Brown, C. (2010). "Plays nice with others": Social-emotional learning and academic success. Early Education and Development, 21(5), 652-680.

Deris, A., \& Di Carlo, C. (2013). Back to basics: Working with young children with autism in inclusive classrooms. Support for Learning, 28(2), 52-56. doi:10.1111/1467-9604.12018

Dewey, J. (1938). Experience and Education. New York: Macmillan, 1959; copyright, 1938, by Kappa Delta Pi).

Dodge, K. A. \& Murphy, R. R. (1984). The assessment of social competence in adolescents. In P. Karoly \& J. Steffen (Eds.). Adolescent behavior disorders: Faundations and contemporary concerns. Advances in child behavioral analysis and therapy. Vol. 3, p 61-96. Lexington, MA: Lexington Books.

Elliott, S.N., \& Busse, R. (2004). Assessment and evaluation of students' behavior and intervention outcomes: The utility of rating scale methods. In R. Rutherford, M. Quinn, \& S. Mathur (Eds.), Handbook of research in emotional and behavioral disorders (pp. 123-142). New York (NY): Guilford Press.

Elliott, S. N., \& Gresham, F. M. (2007). SSIS Classwide Intervention Program. Bloomington, $\mathrm{MN}$ : Pearson Assessments.

Elliott, S. N., Gresham, F. M., L. Frank, J. L., \& Beddow, P. A. (2008). Intervention Validity of Social Behavior Rating Scales. Features of Assessments That Link Results to Treatment Plans. Assessment for Effective Intervention, 34(1), 15-24. 


\section{iejee}

Frankel, F., \& Myatt, R. (2003). Children's friendship training. Brunner-Routledge Friend, M., \& Bursack, W. D. (2009). Including students with special needs: A practical guide for classroom teachers (5th ed.) (pp. 1-33). Upper Saddle River, $\mathrm{NJ}$ : Pearson Education Inc.

Garbarino, J. (1985). Adolescent development: An ecological perspective. Columbus, $\mathrm{OH}$ : Charles E. Merrill.

Gates, J., Kang, E., \& Lerner, M. (2017). Efficacy of group social skills interventions for youth with autism spectrum disorder: a systematic review and meta-analysis. Clinical Psychology Review, 52, 164-181.

Getzels, J. W. \& Jackson, P. W. (1961). Creativity and Intelligence. New York: Wiley.

Goldstein, H., Kaczmarek, L., Penningon, R., \& Shafer, K. (1992). Peer-mediated intervention: Attending to, commenting on, and acknowledging the behavior of preschoolers with autism. Journal of Applied Behavior Analysis, 25, 289-305.

Gotham, K., Brunwasser, S. M., \& Lord, C. (2015). Depressive and anxiety symptom trajectories from school age through young adulthood in samples with autism spectrum disorder and developmental delay. Journal of the American Academy of Child and Adolescent, 54, 369-376.

Gray, C. (2004). Social stories 10.0: The new defining criteria \& guidelines. Jenison Autism Journal, 15(4), 2-21.

Gray, C. (2010). The new social story book. Arlington, TX: Future Horizons.

Gray, C. (2021). Carol Gray Social Stories 10.3 Online - a Presentation by Carol Gray [PowerPoint slides]. Virtual Presentation, February 11, 2021

Gray, C., Broek, E., Cain, S. L., Dutkiewicz, M., Fleck, C., Gray, B., Gray, ... Moore, L. (1993). The social story book. Jenison, Ml: Jenison Public Schools.

Gresham, F. M. (1986). Conceptual and Definitional issues in the Assessment of Children's Social Skills: Implications for Classifications and Training. Journal of Clinical Child Psychology, 15(1), 3-15, DOI: 10.1207/s15374424jccp1501_1

Gresham, F. M. (2016). Social skills assessment and intervention for children and youth. Cambridge Journal of Education, 46(3), 319-332. http:// dx.doi.org/10.1080/0305764X.2016.1195788
Gresham, F. M. \& Elliott, S. N. (2014). Social Skills Assessment and Training in Emotional and Behavioral Disorders. In H. M. Walker \& F. M. Gresham (Eds.). Handbook of evidencebased practices for emotional and behavioral disorders: Applications in schools. New York: Guilford, Inc. (p. 152-172)

Gresham, F. M., \& Elliott, S. N. (1990). The social skills rating system. Circle Pines, MN: American Guidance Service.

Gresham, F. M., Sugai, G., \& Horner, R. H. (2001). Interpreting outcomes of social skills training for students with high-incidence disabilities. Exceptional Children, 67(3), 331-344.

Gresham, F. M., Van, M. B., \& Cook, C.R. (2006). Social skills training for teaching replacement behaviors: Remediating acquisition deficits in at-risk students. Behavioral Disorders, 31(4), 363377.

Guralnick, M. J. (1990). Social competence and early intervention. Journal of Early Intervention, 14(1), 3-14.

Han, H.S. \& Kemple, K.M. (2006). Components of Social Competence and Strategies of Support: Considering What to Teach and How. Early Childhood Education Journal, 34, 241-246. https://doi.org/10.1007/s10643-006-0139-2

Hansen, S., Blakely, A., Dolata, J., Raulston, T., \& Machalicek, W. (2014). Children with autism in the inclusive preschool classroom: A systematic review of single-subject design interventions on social communication skills. Review Journal of Autism Developmental Disorders, 1, 192-206. doi:10.1007/s40489-014-0020-y

Harper, C. B., Symon, J. B. G., \& Frea, W. D. (2008). Recess is time-in: Using peers to improve social skills of children with autism. Journal of Autism Developmental Disorders, 38(5), 815-826. doi:10.1007/s10803-007-0449-2

Hebron, J., Humphrey, N., \& Oldfield, J. (2015). Vulnerability to bullying of children with autism spectrum conditions in mainstream education: a multi-informant qualitative exploration. Journal of Research in Special Educational Needs, 15(3), 185-193. 
Hillier, A. J., Fish, T., Siegel, J. H., \& Beversdorf, D. Q. (2011). Social and vocational skills training reduces self-reported anxiety and depression among young adults on the autism spectrum. Journal of Developmental and Physical Disabilities, 23, 267 - 276. doi:10.1007/s10882-011-9226-4

Howlin, P., Magiati, I., Charman, T. \& MacLean, Jr. W.E. (2009). Systematic Review of Early Intensive Behavioral Interventions for Children with Autism. American Journal on Intellectual Developpmental Disability, 114(1). 23-41.

Hume, K., Loftin, R., \& Lantz, J. (2009). Increasing independence in autism spectrum disorders: A review of three focused interventions. Autism and Developmental Disorders, 39(9), 1329-1338.

Humphrey, N., \& Symes, W. (2013). Inclusive education for pupils with autistic spectrum disorders in secondary mainstream schools: Teacher attitudes, experience and knowledge. International Journal of Inclusive Education, 17(1), 32-46. doi:10.1080/13603116.2011.580462

Hutchins, T. L., \& Prelock, P. A. (2013). The social validity of Social Stories ${ }^{\text {TM }}$ for supporting the behavioural and communicative functioning of children with autism spectrum disorder. International Journal of Speech-Language Pathology, 15(4), 383- 395.

Hwang, B., \& Hughes, C. (2000). The effects of social interactive training on early social communicative skills of children with autism. Journal of Autism and Developmental Disorders, 30(4), 331-343. doi:10.1023/a:1005579317085.

Ingersoll, B., Schreibman, L., \& Stahmer, A. (2001). Brief report: Differential treatment outcomes for children with autistic spectrum disorder based on level of peer social avoidance. Journal of Autism and Developmental Disorders, 31, 343349

Ingersoll, B., \& Schreibman, L. (2006). Teaching reciprocal imitation skills to young children with autism using a naturalistic behavioral approach: Effects on language, pretend play, and joint attention. Journal of Autism and Developmental Disorders, 36(4), 487-505. doi:10.1007/s10803-006-0089-y

Jamison, K. R., Forston, L. D., \& Stanton-Chapman, T. L. (2012). Encouraging social skill development through play in early childhood special education classrooms. Young Exceptional Children, 15, 3-19.
Jansen, J. \& Holck, P. (2020). Hippocampus. Store medisinske leksikon. Hentet fra https://sml.snl.no/ hippocampus [Hippocamous. Comprehensive Medical Lexicon, accessed 09. September 2020, https://sml.snl.no/hippocampus]

Jones, D.E., Greenberg, M., \& Crowley, M. (2015). Early social-emotional functioning and public health: the relationship retween kindergarten social competence and future wellness. American Journal of Public Health, 105(11), 2283-2290. doi:10.2105/ajph.2015.302630

Jones, R., Pickles, A., \& Lord, C. (2017). Evaluating the quality of peer interactions in children and adolescents with autism with the Penn Interactive Peer Play Scale (PIPPS). Molecular Autism, 8(28), 1-9. doi:10.1186/s13229-017-0144-X

Jonsson, U., Olsson, N. C., \& Bölte, S. (2016). Can findings from randomized controlled trials of social skills training in autism spectrum disorder be generalized. The neglected dimension of external validity. Autism: The International Journal of Research and Practice, 20, 295-305, https://doi.org/10.1177/1362361315583817

Kamps, D., Thiemann-Bourque, K., Heitzman-Powell, L., Schwartz, I., Rosenberg, N., Mason, R., \& Cox, S. (2015). A comprehensive peer network intervention to improve social communication of children with autism spectrum disorders: A randomized trial in kindergarten and first grade. Journal of Autism and Developmental Disorders, 45(6), 1809-1824. http://doi.org/10.1007/s10803014-2340-2

Kasari, C., Freeman, S., \& Paparella, T. (2006). Joint attention and symbolic play in young children with autism: a randomized controlled intervention study. Journal of Child Psychology and Psychiatry, 47, 611-620.

Kasari, C., \& Smith, T. (2013). Interventions in schools for children with autism spectrum disorder: Methods and recommendations. Autism, 17, 254-267. [PubMed: 23592848].

Kasari, C., Locke, J., Gulsrud, A., \& Rotheram-Fuller, E. (2011). Social networks and friendships at school: Comparing children with and without ASD. Journal of Autism and Developmental Disorders, 41(5), 533-544. doi:10.1007/s10803-0101076-x 


\section{iejee $\approx$}

Kasari, C., Rotheram-Fuller, E., Locke, J., \& Gulsrud, A. (2012). Making the connection: Randomized controlled trial of social skills at school for children with autism spectrum disorders. Journal of Child Psychology and Psychiatry, and Allied Disciplines, 53(4), 431-439. doi:10.1111 j.1469-7610.2011.02493

Kasari, C., \& Chang, Y. C. (2014). Play development in children with Autism Spectrum Disorders : Skills, object play, and interventions. In F. R. Volkmar, R. Paul, S. J. Rogers, \& K. A. Pelphrey (Eds.), Handbook of autism and pervasive developmental disorders (pp. 263-277). Hoboken, NJ: John Wiley \& Sons

Kasari, C., Dean, M., Kretzmann, M., Shih, W., Orlich, D., Whitney, R., Landa, R., ... King, B. (2015). Children with autism spectrum disorder and social skills groups at school: A randomized trial comparing intervention approach and peer composition. Journal of Child Psychology and Psychiatry, 57(2), 171-179.

Katz L. G., McClellan D. E., (1997). Fostering children's social competence: The teacher's role. Washington, DC: NAEYC

Klintwall, L. \& Eikeseth, S. (2014). Early and Intensive Behavioral Intervention (EIBI) in Autism. I V.B. Patel, V.R. Preedy \& C.R. Martin (eds.), Comprehensive Guide to Autism (s. 117-138). New York: Springer.

Koegel R.L. \& Koegel L.K. (2006). Pivotal Response treatments for autism: Communication, social \& academic development. Baltimore, MD: Paul H. Brookes.

Koegel, R. L., Kim, S., Koegel, L., \& Schwartzman, B. (2013). Improving socialization for high school students with ASD by using their preferred interests. Journal of Autism and Developmental Disorders, 43, 2121-2134

Koegel, L. K., Koegel, R. L., Ashbaugh, K., \& Bradshaw, J. (2014). The importance of early identification and intervention for children with or at risk for autism spectrum disorders. International Journal of Speech-Language Pathology, 16(1), 50-56. doi:10.3109/17549507.2013.861511

Kok, B. E., Coffey, K. A., Cohn, M. A., Catalino, L. I., Vacharkulksemsuk, T., Algoe, S. B., Brantley, M., ... Fredrickson, B. L. (2013). How positive emotions build physical health: Perceived positive social connections account for the upward spiral between positive emotions and vagal tone. Psychological Science, 24(7), 1123-1132. doi:10.1177/0956797612470827
Kokina, A., \& Kern, L. (2010). Social story interventions for students with autism spectrum disorders: A meta-analysis. Journal of Autism and Developmental Disorders, 40(7), 812-826

Lamer, K. (1997). Du og jeg og vi to: Teoriboka: Om å fremme barns sosiale kompetanse teoriboka [You and me and the two of us: The theory book: About increasing children's social competence]. Oslo, Norway: Universitetsforlaget.

Lamer, K. (2006). Evaluering og videreutvikling av Du og jeg og vi to [Evaluation and further development of you and me and the two of us]. In K. Lamer, \& S. Hauge (Eds.), Fra rammeprogram til handling. Implementering av rammeprogrammet [From framework plan to action] (HiO Report 28). Oslo, Norway: Oslo and Akershus University College of Applied Sciences.

Lauderdale-Litten, S., Howell, E., \& Blacher, J. (2013). Educational placement for children with autism spectrum disorders in public and non-public school settings: The impact of social skills and behavior problems. Education and Training in Autism and Developmental Disabilities, 48(4), 469 - 478.

Laugeson, E. A., Frankel, F., Mogil, C., \& Dillon, EN. R. (2009).Foreldreassistert sosial ferdigheter opplæring til forbedre vennskap iungdommer med autisme spektrum forstyrrelser. Tidsskrift av Autisme og Utviklingsmessig Forstyrrelser, 39(4), 596-606

Laugeson, E. A., \& Frankel, F. (2010). Social skills for teenagers with developmental and autism spectrum disorders: The PEERS treatment manual. Routledge.

Laugeson, E. A., Frankel, F., Gantman, A., Dillon, A. R., \& Mogil, C. (2012). Evidence-based social skills training for adolescents with autism spectrum disorders: The UCLA PEERS program. Journal of Autism and Developmental Disorders, 42(6), 1025-1036.

Laugeson, E. A., \& Park, M. N. (2014). Using a CBT approach to teach social skills to adolescents with autism spectrum disorder and other social challenges: the PEERS ${ }^{\circledast}$ method. Journal of Rational-Emotive \& Cognitive-Behavior Therapy, 32(1), 84-97. 
Leaf, J.B., Leaf,J.A., Milne, C., Taubman, M., OppenheimLeaf, M., Torres, N., Townley-Cochran, D., Leaf, R., McEachin, J., Yoder, P. (2017). Autism Partnership Foundation. An Evaluation of a Behaviorally Based Social Skills Group for Individuals Diagnosed with Autism Spectrum Disorder. Journal of Autism and Developmental Disorders. 47(2):243-259. doi: 10.1007/s10803-0162949-4. PMID: 27807755.

Leffert, N., Benson, P. L., \& Roehlkepartan J. L., (1997). Starting out right: Developmental assets for children. Minneapolis, MN: Search Institute.

LeGoff, D. B. (2004). Use of LEGO@ as a therapeutic medium for improving social competence. Journal of Autism and Developmental Disorders, 34(5), 557-571.

Lindsay, S., Proulx, M., Thomson, N., \& Scott, H. (2013). Educators' challenges of children with autism spectrum disorder in mainstream classrooms. International Journal of Disability, Development and Education, 60(4), 347-362. doi:10.1080/10349 $12 \times .2013 .846470$.

Locke, J., Ishijima, E. H., Kasari, C., \& London, N. (2010). Loneliness, friendship quality and the quality and the social networks of adolescents with high-functioning autism in an inclusive school setting. Journal of Research in Special Educational Needs, 10(2), 74-81.

Locke, J., Rotheram-Fuller, E., \& Kasari, C. (2012). Exploring the social impact of being a typical peer model for included children with autism spectrum disorder. Journal of Autism Developmental Disorders, 42(9), 1895-1905. doi:10.1007/s10803011-1437-0

Locke, J., Beidas, R. S., Marcus, S., Stahmer, A., Aarons, G. A., Lyon, A. R., ... Mandell, D. S. (2016). A mixed methods study of individual and organizational factors that affect implementation of interventions for children with autism in public schools. Implementation Science, 11(135). doi:10.1186/s13012-016-0501-8

Løkken, I. M., Broekhuizen, M. L., Moser, T., Bjørnestad, E., \& Hegna, M. M. (2018). Evaluation of the Lamer Social Competence in Preschool Scale. Tidsskrift for Nordisk Barnehageforskning, 17(9), 1-22. DOI: $10.7577 /$ nbf.2424
Magiati, I., Tay, Z., \& Howlin, P. (2013). Cognitive, language, social and behavioural outcomes in adults with autism spectrum disorders: A systematic review of longitudinal follow up studies in adulthood. Clinical Psychology Review, 34(1), 73-86.

Makin, C., Hill, V., \& Pellicano, E. (2017). The primary-to-secondary school transition for children on the autism spectrum: A multiinformant mixed-methods study. Autism and Developmental Language Impairments, 2, 1-18. doi:10.1177/2396941516684834.

Mason, R., Ganz, J., Parker, R., Burke, M., \& Camargo, S. (2012). Moderating factors of video modeling with other as model: A meta-analysis of singlecase studies. Research in Developmental Disabilities, 33(4), 1076-1086.

Matson, J. L., \& Boisjoli, J. A. (2008). The token economy for children with intellectual disability and/or autism: A review. Research in Developmental Disabilities, 30, 240-248. doi:10.1016/j. ridd.2008.04.00

Mayton, M. R., Menendez, A. L., Wheeler, J. J., Carter, S. L., \& Chitiyo, M. (2013). An analysis of Social Stories $^{\mathrm{TM}}$ research using an evidence-based practice model. Journal of Research in Special Educational Needs, 13(3), 208-217.

Mazurek, M. O., Kanne, S. M., \& Wodka, E. L. (2013). Physical aggression in children and adolescents with autism spectrum disorders. Research in Autism Spectrum Disorders, 7(3), 455-465. doi:10.1016/j.rasd.2012.11.004

McFadden, B., Kamps, D., \& Heitzman-Powell, L. (2014). Social communication effects of peermediated recess intervention for children with autism. Research in Autism Spectrum Disorders, 8(12), 1699-1712. doi:10.1016/j.rasd.2014.08.015

Mead, G. H. (1934). Mind, Self and Society. Chicago: University of Chicago Press.

Meadan, H., Halle, J. W., \& Ebata, A. T. (2010). Families with children who have autism spectrum disorders: Stress and support. Exceptional Children, 77, 7-36.

Miller, M., Young, G. S., Hutman, T., Johnson, S., Schwichtenberg, A. J., \& Ozonoff, S. (2015). Early pragmatic language difficulties in siblings of children with autism: Implications for DSM-5 Social Communication Disorder? Journal of Child Psychology and Psychiatry, and Allied Disciplines, 56(7), 774-781. http://doi.org/10.1111/ jсpp.12342 


\section{iejee}

Montroy, J. J., Bowles, R. P., Skibbe, L. E., \& Foster, T. D. (2014). Social skills and problem behaviors as mediators of the relationship between behavioral self-regulation and academic achievement. Early Childhood Research Quarterly, 29(3), 298-309.

Mordre, M., Groholt, B., Knudsen, A. K., Sponheim, E., Mykletun, A., \& Myhre, A. M. (2012). Is longterm prognosis for pervasive developmental disorder not otherwise specified different from prognosis for autistic disorder? Findings from a 30-year follow-up study. Journal of Autism and Developmental Disorders, 42(6), 920-928.

Munkhaugen, E., Gievik, E., Pripp, A., Sponheim, E., \& Diseth., T. (2017). School refusal behaviour: Are children and adolescents with autism spectrum disorder at a higher risk? Research in Autism Spectrum Disorders, 41-42, 31-38.

Nangle, D. F., Grover, R. L., Holleb, L., Cassano, J., M., \& Fales, J. (2010). Defining competence and identifying target skills. In D. W. Nangle, D. J. Hansen, C. A. Erdley \& P. J. Norton (Eds.), Practitioner's guide to empirically based measures of social skills. New York, NY: Springer. (p. 3-19).

Nealy, C. E., Ohare, L., Powers, J. D., \& Swick, D. C. (2012). The impact of autism spectrum disorders on the family: A qualitative study of mothers' perspectives. Journal of Family Social Work, 15(3), 187-201. doi:10.1080/10522158.2012.675624

Nik Adib, N. A., Ibrahim, M. I., Ab Rahman, A., Bakar, R. S., Yahaya, N. A., Hussin, S., \& Wan Mansor, W. (2019). Perceived Stress among Caregivers of Children with Autism Spectrum Disorder: A State-Wide Study. International Journal of Environmental Research and Public Health, 16(8), 1468. https:// doi.org/10.3390/ijerph16081468

Odom, S. L., McConnell, S. R., McEvoy, M. A., Peterson, C., Ostrosky, M., Chandler, L. K., Spicuzza, R. J., Skellenger, A., Creighton, M., \& Favazza, P. C. (1999). Relative effects of interventions supporting the social competence of young children with disabilities. Topics in Early Childhood Special Education, 19(2), 75-91.

Ogden, T. \& Hagen, K. A. (2019). Adolescent Mental Health Prevention and Intervention. 2nd edition. Routledge.
Orpinas, P. (2010). Social competence. In W. Edward Graighead \& I. B. Weiner (Eds.) The Corsini Encyclopedia of Psychology. 4th ed. John Wiley \& Sons ( $p$ 1623-1625)

Orsmond, G. I., Krauss,M. W., \& Seltzer, M. M. (2004). Peer relationships and social and recreational activities among adolescents and adults with autism. Journal of Autism and Developmental Disorders, 34(3),245-56.

Owens, G., Granader, Y., Humphrey, A. \& Baron-Cohen, S. (2008). LEGO $^{\circledR}$ therapy and the Social Use of Language Programme: an evaluation of two social skills interventions for children with high functioning autism and Asperger syndrome. Journal of Autism and Developmental Disorders, 38(10), 1944-1957.

Owens, J. S., Lyon, A. R., Brandt, N. E., Warner, C. M., Nadeem, E., Spiel, C., \& Wagner, M. (2014). Implementation science in school mental health: Key constructs in a developing research agenda. School Mental Health, 6(2), 99-111.

Özerk, M. \& Özerk, K. (2020). Autisme og Pedagogikk [Autism and pedagogy]. Oslo: CappelenDamm Akademisk Forlag.

Pane, H. M., Sidener, T. M., Vladescu, J. C., \& Nirgudkar, A. (2015). Evaluating function-based social stories ${ }^{\mathrm{T} M}$ with children with autism. Behavior Modification, 39(6), 912-931. doi:10.1177/0145445515603708

Patton, D. U., Hong, J. S., Patel, S., \& Kral, M. J. (2016). A systematic review of research strategies used in qualitative studies on school bullying and victimization. Trauma, Violence, \& Abuse, 18(1), 3-16. doi:10.1177/1524838015588502

Petalas, M. A., Hastings, R. P., Nash, S., Reilly, D., \& Dowey, A. (2012). The perceptions and experiences of adolescent siblings who have a brother with autism spectrum disorder. Journal of Intellectual and Developmental Disability, 37(4), 303-314. doi :10.3109/13668250.2012.734603.

Piaget, J. (1977/1995). Sociological studies. London: Routledge.

Pierce-Jordan, S., \& Lifter, K. (2005). Interaction of social and play behaviors in preschoolers with and without pervasive developmental disorder, Topics in Early Childhood Special Education, 25, 34-47. 
Plavnick, J. B., Kaid, T., \& MacFarland, M. C. (2015). Effects of a school-based social skills training program for adolescents with autism spectrum disorder and intellectual disability, Journal of Autism and Developmental Disorders, 45(9), 2674-2690. doi:10.1007/s10803-015-2434-5

Platos, M., \& Wojaczek, K. (2017). Broadening the scope of peer-mediated intervention for individuals with Autism Spectrum disorders. Journal of Autism and Developmental Disorders, 48(3), 747750.

Rabiner, D., Godwin, J., \& Kenneth, A. (2016). Predicting academic achievement and attainment: The contribution of early academic skills, attention difficulties, and social competence. School Psychology Review, 45(2), 250 -267.

Reichow, B., \& Volkmar, F. R. (2010). Social skills interventions for individuals with autism: Evaluation for evidence-based practices with a best evidence synthesis framework. Journal of Autism and Developmental Disorders, 40, 149166. doi:10.1007/s10803-0090842-0

Reichow, B., Barton, E. E., Boyd, B. A., \& Hume, K. (2012). Early intensive behavioral intervention (EIBI) for young children with autism spectrum disorders (ASD). The Cochrane Database of Systematic Reviews, 10, CD009260. doi:10.1002/14651858. CD009260.pub2

Rodríguez-Medina, J., Martín-Antón, L. J., Carbonero, M. A., \& Ovejero, A. (2016). Peer-mediated intervention for the development of social interaction skills in high-functioning autism spectrum disorder: A pilot study. Frontiers in Psychology, 7, 1-11. doi:10.3389/fpsyg.2016.01986

Rogers, S.J. \& Dawson, G. (2010). Early start Denver model for young children with autism: Promoting language, learning, and engagement. New York: The Guilford Press.

Rumsey, J., Rapoport, J., \& Sceery, W. (1985). Autistic children as adults: Psychiatric, social, and behavioral outcomes. Journal of the American Academy of Child Psychiatry, 24, 465-473.

Rutter, M. \& Pine, D.S. (2015). Diagnosis, diagnostic formulations, and classification. In A. Thapar, D. S. Pine, J.E. Leckman, S. Scott, M.J. Snowling \& E. Taylor (Red.), Rutter's Child and Adolescent Psychiatry (s. 17-30). Hoboken, NJ: John Wiley \& Sons Ltd.
Santomauro, D., Sheffield, J., \& Sofronoff, K. (2016). Investigations into emotion regulation difficulties among adolescents and young adults with autism spectrum disorder: A qualitative study. Journal of Intellectual \& Developmental Disability, 42(3), 275-284. doi:10.3109/13668250.20 16.1236240

Schlieder, M., Maldonado, N., \& Baltes, B. (2014). An investigation of "Circle of Friends" peer mediated intervention for students with autism. The Journal of Social Change, 6(1), 27-40. doi:10.5590/JOSC.2014.06.1.0

Schneider, B. H. (1993). Children's social competence in context: The contributions of family, school and culture. Oxford: Pergamon Press.

Schonert-Reichl, K. A., \& Hymel, S. (2007). Educating the heart as well as the mind: why social and emotional learning is critical for students' school and life success. Education Canada, 47, 20-25.

Schriebman, L., Stahmer, A., \& Pierce, K. (1996). Alternative applications of pivotal response training: Teaching symbolic play and social interaction skills. In: L. Koegel, R. Koegel, \& G. Dunlap, G., (Eds.). Positive behavioral support: Including people with difficult behavior in the community, (pp. 353-371). Baltimore, MD: Paul H. Brookes.

Schroeder, J. H., Cappadocia, M. C., Bebko, J. M., Pepler, D. J., \& Weiss, J. A. (2014). Shedding light on a pervasive problem: A review of research on bullying experiences among children with autism spectrum disorders. Journal of Autism and Developmental Disorders, 44(7), 1520-1534. doi:10.1007/s10803-013-2011-8

Seppala, E., Rossomando, T., \& Doty, J. (2013). Social connection and compassion: Important predictors of health and well-being. Social Research, 80(2), 411-430. Retrieved from http:// www.jstor.org/stable/24385608

Shaked, M., \& Yirmiya, N. (2003). Understanding social difficulties. In M. Prior (Ed.), Learning and behavior problems in Asperger syndrome (pp.126-147). New York, NY: Guilford Press.

Silveira-Zaldivar, T. (2019). Utilizing participatory action research to implement evidence-based social skills interventions for elementary students with high functioning autism in inclusive classroom settings. Ph.D. Dissertation. Northwest Nazarene University. 


\section{iejee $\sqrt{2}$}

Silveira-Zaldivar, T. \& Curtis, H. (2019). "I'm not trained for this!" Barriers to evidence-based social skills interventions for elementary students with high functioning autism in inclusion: social skills interventions for elementary students. International Electronic Journal of Elementary Education, 12(1), 53-66.

Stahmer, A., Reed, S., Lee, E., Reisinger, E. M., Connell, J. E., \& Mandell, D. S. (2015). Training teachers to use evidence-based practices for autism: Examining procedural implementation fidelity. Psychology in the Schools, 52(2), 181-195. doi:10.1002/pits. 21815

Staikova, E., Gomes, H., Tartter, V., McCabe, A., \& Halperin, J. M. (2013). Pragmatic deficits and social impairment in children with ADHD. Journal of Child Psychology and Psychiatry, and Allied Disciplines, 54(12), 1275-1283. doi:10.1111/ jcpp.12082.

Steinbrenner, J. R., Hume, K., Odom, S. L., Morin, K. L., Nowell, S. W., Tomaszewski, B., Szendrey, S., Mclntyre, N. S., Yücesoy-Özkan, S., \& Savage, M. N. (2020). Evidence-based practices for children, youth, and young adults with Autism. The University of North Carolina at Chapel Hill, Frank Porter Graham Child Development Institute, National Clearinghouse on Autism Evidence and Practice Review Team.

Szatmari, P., Bryson, S. E., Boyle, M. H., Streiner, D. L., \& Duku, E. (2003). Predictors of outcome among high functioning children with autism and Asperger syndrome. Journal of Child Psychology and Psychiatry, 44, 520-528. doi:10.1111/14697610.00141.

Szumski, G., Smogorzewska, J., Grygiel, P., \& Orlando, A-M. (2019) Examining the Effectiveness of Naturalistic Social Skills Training in Developing Social Skills and Theory of Mind in Preschoolers with ASD. Journal of Autism and Developmental Disorders, 49, 2822-2837 https://doi.org/10.1007/ s10803-017-3377-9.

Tager-Flusberg, H. (2003). Effects of language and communicative deficits on learning and behavior. In M. Prior (Ed.), Learning and behavior problems in Asperger syndrome (pp. 85-103). New York, NY: Guilford Press.

Taylor, J. L., \& Henninger, N. A. (2015). Frequency and correlates of service access among youth with autism transitioning to adulthood. Journal of Autism Developmental Disorders, 45(1), 179-19. doi:10.1007/s10803-014-2203-X.
Tierney, C. D., Kurtz, M., Panchik, A., \& Pitterle, K. (2014). 'Look at me when I am talking to you': Evidence and assessment of social pragmatics interventions for children with autism and social communication disorders. Current Opinion in Pediatrics, 26(2), 259-264. doi:10.1097/ mop.0000000000000075.

Thorndike, E. L. (1927). The measurement of intelligenze. New York: Columbia University, Teachers College, Bureau of Publications.

Tsilioni, I., Pantazopoulos, H., Conti, P., Leeman, S.E. \& Theoharides, T.C. (2020). IL-38inhibits microglial inflammatory mediators and is decreased in amygdala of childrenwith autism spectrum disorder. Proceedings of the National Academy of Sciences, 117(28), 16475-16480.

Van Steensel, F., Deutschman, A., \& Bogels, S. (2012). Anxiety and quality of life: Clinically anxious children with and without autism spectrum disorders compared. Journal of Clinical Child \& Adolescent Psychology, 41(6), 731-738. doi:10.1080 /15374416.2012.698725

Vygotsky, L. S. (1978). Mind in society: The development of higher psychological processes. Cambridge, MA: Harvard University Press.

Vygotsky, L. (1986). Thought and language (Edited by A. Kozulin). Cambridge: MIT.

Walker, L. O., Freeland-Graves, J. H., Milani, T., HanssNuss, H. , George, G., Sterling, B. S., Kim, M., Timmerman, G. M., Wilkinson, S., Arheart, K. L., \& Stuifbergen, A. (2004) Weight and behavioral and psychosocial factors among ethnically diverse, low income women after childbirth: i. methods and context. Women \& Health, 40(2), 1-17, DOI:10.1300/J013v40n02_01

Wang, S. Y., Cui, Y., \& Parrila, R. (2011). Examining the effectiveness of peer-mediated and videomodeling social skills interventions for children with autism spectrum disorders: A metaanalysis in single-case research using HLM. Research in Autism Spectrum Disorders, 5(1), 562-569. doi:10.1016/j.rasd.2010.06.023

Wetherby, A. M., Watt, N., Morgan, L., \& Shumway, S. (2007). Social communication profiles of children with autism spectrum disorders late in the second year of life. Journal of Autism and Developmental Disorders, 37, 960-975. 
Whalon, K., Conroy, M., Martinez, J., \& Werch, B. (2015). School-based peer-related social competence interventions for children with autism spectrum disorder: A meta-analysis and descriptive review of single case research design studies. Journal of Autism \& Developmental Disorders, 45(6), 1513-1531. doi:10.1007/s10803-015-2373-1.

Whitcomb, S. A. (2018). Behavioral, social, and emotional assessment of children and adolescents. Fifth Edition. London: Roudledge.

White, R. W. (1959). Motivation reconsidered. The concept of competence. Psychological Review. 66, 297-333.

White, S. W., Keonig, K., \& Scahill, L. (2007). Social skills development in children with autism spectrum disorders: A review of the intervention research. Journal of Autism and Developmental Disorders. $37,1858-1868$

Williams White, S., Keonig, K., \& Scahill, L. (2007). Social skills development in children with autism spectrum disorders: A review of the intervention research. Journal of Autism Disorders, 37(10), 1858-1868. doi:10.1007/s10803-006-0320-x.

WHO (2020). Manual of the international statistical classification of diseases, injuries, and causes of death. Genève: World Health Organization.

Witherell, S. L. (2013). "Work-related stress and mental health of child care center workers" Wayne State University Dissertations. Paper 718.

Wolfberg, P., De Witt, M., Young, G., \& Nguyen, T. (2015). Integrated play groups: Promoting symbolic play and social engagement with typical peers in children with ASD across settings. Journal of Autism and Developmental Disorders, 45(3), 830-845. doi:10.1007/s10803-014-2245-0.

Wolstencroft, J., Robinson, L., Srinivasan, R., Kerry, E., Mandy, W., \& Skuse, D. (2018). A systematic review of group social skills interventions, and meta-analysis of outcomes, for children with high functioning ASD. Journal of Autism and Developmental Disorders, 48(7), 2293-2307. doi:10.1007/s10803-018-3485-1.

Wong, C., Odom, S. L., Hume, K., Cox, A. W., Fettig, A., Kucharczyk, S., ... Schultz, T. R. (2015). Evidencebased practices for children, youth, and young adults with autism spectrum disorder: A comprehensive review. Journal of Autism and Developmental Disorders, 45(7), 1951-1966.
Zablotsky, B., Bramlett, M., \& Blumberg, S. J. (2015). Factors associated with parental ratings of condition severity for children with autism spectrum disorder. Disability and Health Journal, 8(4), 626634. doi:10.1016/j.dhjo.2015.03.006.

Zagona, A., \& Mastergeorge, A. (2016). An empirical review of peer-mediated interventions. Focus on Autism and Other Developmental Disabilities, 33(3), 131-141. doi:10.1177/1088357616671295.

Zins, J., Weissberg, R., Wang, M., \& Walberg, H. (2004). Building academic success on social and emotional learning. New York, NY: Teachers' college Press. 